\title{
POZNAWCZA GENEZA JEZZYKA A INFORMACYJNA STRUKTURA ZNACZENIA
}

Streszczenie. W pracy została przedstawiona propozycja wyjaśnienia różnorodnych aspektów, w jakich przejawia się znaczenie językowe w poznaniu i komunikacji z perspektywy poznawczej genezy języka. Język został ujęty jako element systemu reprezentacji poznawczych, w którym zachodzą określone procesy przetwarzania informacji. Procesy informacyjne w układzie poznawczym człowieka leżą u podstaw związku języka z poznaniem świata i działaniem użytkownika języka w świecie. Są też one źródłem znaczenia językowego i jego różnorakich funkcji informacyjnych.

Przeprowadzona analiza pokazuje, że nie można mówić o jednej funkcji informacyjnej znaczenia. To, co uznajemy za znaczenie (w sensie informacji przekazanej przez wyrażenia w konkretnej sytuacji), nie jest jedną funkcją języka, taką samą we wszystkich wymienionych procesach, lecz wiązką różnych funkcji informacyjnych jakie pełni język, od znaczenia konwencjonalnego po kontekstowe. Takie ujecie zagadnienia pozwala wskazać wzajemne warunkowanie się różnych funkcji i aspektów znaczenia i ujmować je jako komplementarne a nie opozycyjne.

Słowa kluczowe: język, znaczenie, reprezentacje poznawcze, informacja, informacyjna struktura reprezentacji

1. Wstęp. 2. Informacyjna geneza reprezentacji poznawczych. 3. Poziomy struktury reprezentacji poznawczych. 4. Rola i miejsce języka w systemie reprezentacji poznawczych. 5. Znaczenia językowe jako dynamiczne struktury informacyjne. 6. Podsumowanie.

Janina Buczkowska janina.buczkowska@uksw.edu.pl
Uniwersytet Kardynała Stefana Wyszyńskiego w Warszawie, Instytut Filozofii Wóycickiego 1/3, 01-938, Warszawa 


\section{WSTEPP}

Dwudziestowieczne dyskusje wokół natury znaczenia zaowocowały licznymi choć nierozstrzygniętymi sporami o to, czym są znaczenia językowe i jaka jest ich natura. Toczą się spory o to, czy znaczenia słów są jednakowe dla wszystkich użytkowników języka i dla wszystkich przypadków użycia? ${ }^{1}$, ponieważ są wyznaczone systemowo ${ }^{2}$ lub zewnętrznie ${ }^{3}$, czy też zależą od indywidualnej wiedzy i doświadczenia mówiącego? Czy znaczenie zmienia się zależnie od kontekstu i sytuacji wypowiedzi, czy też jest w stosunku do nich autonomiczne? Czy znaczenie ma charakter wiedzy encyklopedycznej, czy też jest rodzajem szczególnej kompetencji językowej? ${ }^{4}$ We współczesnych dyskusjach przeciwstawia się często literalne i kontekstowe rozumienie znaczenia. Podobnie znaczenie rozumiane w wymiarze uniwersalnym jako element systemu języka jest przeciwstawiane znaczeniu indywidualnemu przynależnemu do idiolektu właściwemu pojedynczemu użytkownikowi. Te i inne dyskutowane współcześnie problemy odnośnie znaczenia łączą się ściśle z pytaniem o naturę języka i jego związki z ludzkim poznaniem i działaniem (szczególnie komunikacyjnym). Podstawowe wyzwanie stanowi wyjaśnienie sposobu w jaki informacja o otoczeniu uzyskana w poznaniu jest organizowana językowo i przekazywana w komunikacji.

Wiele ważnych pytań odnośnie do komunikacyjnych funkcji języka związanych jest z problemem poznawczej genezy znaczenia językowego.

1 Tak, jak opisuje to T. Nagel w: Co to wszystko znaczy. Bardzo krótkie wprowadzenie do filozofii, tłum. z ang. M. Szczubiałka, Fundacja Aletheia, Warszawa 1998, 43-52.

2 Wynika to $\mathrm{z}$ postulatu holizmu językowego wysuniętego przez W.V.O. Quine'a w Dwa dogmaty empiryzmu, i rozwijanego w jego kolejnych pracach, por. W.V.O. Quine Dwa dogmaty empiryzmu, w: Tenże, Z punktu widzenia logiki, tłum. z ang. B. Stanosz, Fundacja Aletheia, Warszawa 2000, 49-75.

3 Por. argumenty H. Putnama za obiektywnym i zewnętrznym znaczeniem słów, zawarte w Znaczenie wyrazu znaczenie w: tegoż, Wiele twarzy realizmu i inne eseje, tłum z ang. A. Grobler, PWN, Warszawa 1998, 93-184.

4 Patrz np. J. R. Taylor, Kategoryzacja w języku. Prototypy w teorii językoznawczej, tłum. z ang. A. Skucińska, TAiWPN Universitas, Kraków 2001, 120-141. 
Pytania postawione powyżej mogą znaleźć rozstrzygnięcie w kontekście analizy informacyjnych uwarunkowań struktury i funkcji wyrażeń językowych.

Zaproponowane ujęcie, ukazujące język jako element systemu reprezentacji poznawczych, w którym zachodzą określone procesy przetwarzania informacji, pozwala dokonać pewnych rozróżnień związanych z tym, co mamy na myśli, mówiąc o znaczeniu w różnych sytuacjach. Jeśli te rozróżnienia zostaną zachowane, przeciwstawienia aspektu kontekstowego i systemowego znaczenia lub uniwersalnego i związanego z rozumieniem wyrażenia przez indywidualnego użytkownika, będące źródłem wymienionych powyżej sporów, staną się słabsze a leżące u ich podstaw opozycje mogą być ujęte jako komplementarne aspekty znaczenia. Celem artykułu jest pokazanie, że konsekwentne ujęcie języka jako elementu systemu reprezentacji poznawczych pozwala wyróżnić zróżnicowane funkcje informacyjne systemu reprezentacji językowej, z którymi łączą się różne składowe informacji wyznaczającej poszczególne aspekty czy składniki znaczenia. Ich częste nierozróżnianie, określanie wspólnym terminem i utożsamianie, kreuje sztuczne trudności będące przedmiotem wspomnianych powyżej sporów.

Artykuł odwołuje się do bardzo ogólnej idei ujmującej język jako element systemu poznawczego człowieka, rozumianego jako system zdobywania i przetwarzania informacji o świecie. Taka ogólna idea narzuca jednak na analizę tego zagadnienia określone warunki, których respektowanie pokazuje, jak różne funkcje informacyjne nazywane są znaczeniem i jak mylące może być ich nierozróżnianie.

\section{INFORMACYJNA GENEZA REPREZENTACJI POZNAWCZYCH ${ }^{5}$}

Wyjaśnienie zarówno zdolności znaków językowych do posiadania znaczeń, jak też faktu używania ich jako środka uzyskiwania i przekazywania informacji o świecie w procesach komunikacji, odwołuje

Pojęcie informacji będzie rozumiane w klasyczny sposób, zgodnie z rozumieniem Shannona, któremu to rozumieniu dodatkowo przypisywana jest funkcja strukturotwórcza, podobnie jak ujmuje to np. C. Weizsacker, szersze omówienie 
się często do poznawczej genezy języka. Znaczenia wyrażeń zawierają informacje o świecie, a ich nabywanie jest blisko powiązane z procesami percepcji i kategoryzacji. Wyrażenia języka ujmowane jako znaki, podobnie jak pojęcia i wrażenia zmysłowe, posiadają treść odniesioną do czegoś poza nimi samymi i w tym sensie stanowią rodzaj reprezentacji poznawczych. Jednak tylko w szerokim kontekście systemu poznawczego wyrażenia językowe posiadają znaczenia, które przypisują im treści i odnoszą do rzeczywistości pozajęzykowej.

Pojęcie reprezentacji mentalnych choć często przywoływane dla wyjaśnienia procesów poznawczych zachodzących w umyśle, rozumiane jest na wiele różnych sposobów i wciąż odwołuje się w znacznym stopniu do intuicji ${ }^{6}$. Jeśli reprezentacje mentalne rozumie się jako proste stany mózgu (jakkolwiek rozumiane, jako neuronalne, fizyczne, funkcjonalne), to pojawiają się trudności z wyjaśnieniem posiadania treści przedmiotowej. Teoria reprezentacji powinna wyjaśniać, czym jest treść reprezentacji mentalnych $\mathrm{i} w$ jakich procesach jest ona odnoszona do czegoś poza umysłem.

W niniejszym artykule reprezentacje poznawcze, także te wytwarzane w umyśle, są rozumiane jako relacje odzwierciedlające triadyczny związek opisany przez Charlesa S. Peirce’a jako pełny znak. Są one dodatkowo rozumiane jako struktury informacyjne, w których określone związki pomiędzy elementami składowymi i ich role w systemie zostały wyznaczone przez procesy przepływu informacji. ${ }^{7}$ Aby w jakimś systemie informacyjnym mogła zostać wytworzona tak specyficzna relacja jak reprezentacja, system ten powinien spełniać warunki umożliwiające zachodzenie w nim określonych, złożonych procesów przepływu informacji. Jednym z nich jest odpowiednio złożona budowa, która wymaga wcześniej zgromadzonej (i zawartej w jego wewnętrznych strukturach) informacji.

zagadnienia - por. J. Buczkowska, Systemowe rozumienie języka, Wydawnictwo UKSW, Warszawa 2002,140-159.

6 Por. R. Cummnis, Meaning and Mental Representation, MIT Press, London 1989, 2-15.

7 Dokładniej na temat takiego rozumienia reprezentacji pisałam w: J. Buczkowska, O relacyjnej i informacyjnej naturze reprezentacji, Wydawnictwo UKSW, Warszawa 2012, 103-119. 
Funkcja reprezentacji, tak jak rozumie ją Peirce, polega na zastępowaniu reprezentowanego przedmiotu przez coś od niego innego dla kogoś/czegoś trzeciego (jakiegoś odbiorcy, którym może być inny system, inny znak lub inny stan systemu, ogólnie określany jako interpretant), pod jakimś względem, czyli w jakimś sensie. W tym (poznawczym) wypadku jest to dostarczanie dla odbiorcy (interpretanta) przez środek przekazu informacji o czymś innym. Interpretant odbiera tę informację i odnosi ją do przedmiotu jako pewną treść.

Dla relacji reprezentacji jest ważne, aby uzyskana informacja nie powodowała jedynie określonej zmiany stanu odbiorcy (była „czymś”), ale by była też „o” czymś. To „o” czymś jest ważnym warunkiem, koniecznym warunkiem bycia reprezentacją. Informacja „o” przypisuje stanom odbiorcy status bycia o czymś - intencjonalność. Ten element przypisania, uczynienia jakiegoś stanu „o czymś” jest dodatkową informacją, pochodzącą od struktury interpretantu.

W odniesieniu do procesów poznania, przykładem reprezentacji może być wrażenie zmysłowe. Przedmiot zewnętrzny działa na zmysły i wytwarza zmysłowe wrażenie, np. zieleni liścia. To wrażenie, aby być reprezentacją przedmiotu zewnętrznego, jakim jest zielony liść, musi być zinterpretowane jako pewna treść (zieleń) odniesiona do przedmiotu tego oto, teraz postrzeganego i niezdeterminowanego inaczej jak jedynie jako zielony. Tę interpretację zewnętrzności, jak pokazywał Bertrand Russel1 ${ }^{8}$, czerpie się z doświadczenia przedmiotu danego dodatkowo przez inne zmysły lub pamięci innych doświadczeń. Aby jednak poznający zinterpretował wrażenie jako zieleń (oglądanego) liścia, potrzebna jest kolejna interpretacja, odwołująca się do wiedzy pojęciowej. Przepływ informacji dokonuje się więc pomiędzy trzema poziomami organizacji informacji: świata zewnętrznego, wrażeń zmysłowych oraz pojęć i generuje relację reprezentacji realnego przedmiotu (zielonego liścia) w umyśle poznającego.

Nośnik informacji, czyli stan mózgu, znak językowy, doznanie zmysłowe pełni swoją funkcję reprezentacji jedynie w szerszym systemie

8 Por. B. Russell, Miękkie i twarde dane, w: Filozofia percepcji, Fragmenty filozofii analitycznej, tłum. R. Godlewski, red. B. Chwedeńczuk, wyd. Spacja, Warszawa 1995,11-22. 
i wymaga dwojakiego rodzaju związków: tych zachodzących pomiędzy elementami wybranego repertuaru nośników informacji, które ze względu na kierunek przepływu informacji można nazwać relacjami poziomymi, oraz tych wyznaczonych przez przepływ informacji pomiędzy kolejnymi strukturami systemu reprezentacji, czyli przedmiotem, środkiem przekazu i interpretantem, które można nazwać relacjami pionowymi. To, jakie są potencjalne stany możliwe do wyróżnienia zarówno w płaszczyźnie przedmiotu, środka przekazu, jak i interpretantu wpływa na treść przypisaną do reprezentacji.

Dla naszych rozważań ważne jest, że system poznawczy gromadzi i przetwarza informację na dwa sposoby. Po pierwsze, wytwarza trwałe struktury, które są rezultatem zgromadzonej zarówno w rozwoju filogenetycznym jak i osobniczym informacji. Są to struktury niereprezentacyjne ${ }^{9}$, które pełnią funkcje umożliwiające odpowiednią transformację informacji i których występowanie poprzedza i warunkuje występowanie struktur reprezentacyjnych. Po drugie, wytwarza struktury reprezentacyjne, do których należą reprezentacje zmysłowe, pojęciowe, językowe, wiedza o świecie itd. Szczególnie aparat pojęciowy i język stanowią pewną, relatywnie trwałą, społecznie ukonstytuowaną strukturę reprezentacji, nabywaną przez poszczególne jednostki. Posiadanie społecznie zsynchronizowanego systemu pojęć i języka umożliwia jednostce generowanie kolejnych egzemplarzy reprezentacji w aktualnych procesach przepływu informacji. Nie tylko używanie języka w konkretnych aktach mowy, ale też pojęciowa interpretacja każdej informacji chwilowej uzyskiwanej za pomocą zmysłów oraz jej rozumienie jako wiedzy o świecie jest wynikiem przetwarzania informacji chwilowej w kontekście ustalonego systemu reprezentacji pojęciowej i językowej. Dopiero na tle tego rozróżnienia: informacji zgromadzonej w stałej strukturze języka i informacji chwilowej, zdobywanej w jednostkowych aktach poznania i komunikacji, możliwe jest odróżnienie uniwersalnego i kontekstowego aspektu reprezentacji.

9 Podobnie F. Dretske wśród zachodzących w umyśle procesów wyróżnia fakty reprezentacyjne i niereprezentacyjne, por. F. Dretske, Naturalizowanie umystu, tłum. z ang. B. Świątczak, Wydawnictwo IFiS PAN, Warszawa 2004, 21. 
Przedstawione powyżej kierunki przepływu informacji od poziomu niższej organizacji informacji do poziomu informacji bardziej złożonej, od poziomu sygnału do poziomu znaku językowego, uwzględniają interpretację polegającą na dodawaniu do informacji uzyskanej na wejściu, informacji pochodzącej od organizacji danego (wyższego) poziomu. Dodać należy jeszcze, że na każdym poziomie może zachodzić dodatkowa interpretacja polegająca na ujawnianiu relacji wewnątrz poziomowych, w których wyraża się wiedza i doświadczenie zorganizowane jakościowo, pojęciowo czy językowo.

\section{POZIOMY STRUKTURY REPREZENTACJI POZNAWCZYCH}

Jak zostało wyżej wspomniane, w strukturze reprezentacji poznawczych wyróżnia się kilka poziomów organizacji informacji uzyskanej za pomocą zmysłów i przetwarzanej w wiedzę o świecie. Podstawowe poziomy poznania ludzkiego to: poziom jakości i przedmiotów zmysłowych, poziom reprezentacji pojęciowych i językowych oraz szeroko rozumiana wiedza o świecie Tworzenie się reprezentacji wymaga wytwarzania relacji pomiędzy tymi poziomami. Podstawą takiego związku jest przepływ informacji pomiędzy elementami różnych poziomów połączony z jej interpretacją. Każde przekształcanie informacji dokonuje się w jakimś odpowiednim dla danej transformacji układzie, który przekształca sygnały uzyskane na wejściu w sygnały na wyjściu. Są to zazwyczaj wrodzone struktury poznawcze właściwe człowiekowi oraz nabyta struktura języka, która jest zgromadzoną i odpowiednio zorganizowaną informacją o świecie, zaś jej pierwotnym źródłem jest świat zewnętrzny działający na zmysły. Taka zgromadzona i utrwalona informacja staje się dopiero odpowiednio przystosowanym narzędziem interpretacji informacji chwilowej, niezbędnej do aktualnego działania w świecie.

Przetwarzanie informacji dokonuje się w dwu przebiegających równolegle i zależnych od siebie procesach opartych na informacjach docierających do układu z otoczenia. Pierwszy jest procesem tworzenia trwałego i odpowiednio indywidualnie przystosowanego narzędzia poznawczego, czyli systemu reprezentacji świata, drugi to proces interpretacji informacji chwilowej za pomocą uzyskanego narzędzia. Należy 
zatem wyraźnie rozróżnić system reprezentacji trwałych, np. system kategorii, pojęć i system językowy, od reprezentacji wytwarzanych chwilowo do przekazania i interpretacji chwilowej informacji, takich jak wypowiedzi czy wrażenia zmysłowe. Relacja reprezentacji trwałej i reprezentacji chwilowej jest podobna do relacji typów i egzemplarzy.

Fundamentalna jest informacja uzyskiwana w ciągłym kontakcie z rzeczywistością, jest ona podstawą zarówno generowania stałego systemu reprezentacji, jak i wiedzy o zmieniających się stanach otoczenia. Trwały system reprezentacji (schematy pojęciowe, język) stanowi rodzaj przystosowania jednostki do rozpoznawania oraz interpretowania stanów otoczenia i jest wytworzony nie przez ewolucję biologiczną, lecz indywidualnie i społecznie. Zgromadzona w taki relatywnie stabilny system reprezentacji poznawczych informacja staje się narzędziem pozwalającym interpretować informację chwilową o otoczeniu. Np. konkretne, chwilowe doznanie zmysłowe znajduje swoją interpretację jako pojęciowo ujęta własność przedmiotu lub usłyszane słowo, które jest interpretowane zgodnie $\mathrm{z}$ regułami języka jako posiadające określoną treść. Jak zatem odzwierciedla się występowanie wyróżnionych powyżej poziomów poznania w procesie konstytuowania trwałego systemu reprezentacji a następnie w interpretacji informacji chwilowych?

Pierwszym etapem tego procesu jest powstanie systemu reprezentacji zmysłowych otoczenia. Receptory zmysłowe dostarczają informacji zorganizowanych na poziomie zmysłowym w związki rozpoznawalnych jakości zmysłowych, dostarczających obrazów zmysłowych przedmiotów jednostkowych, posiadających odpowiednie cechy, np. kształt, wielkość, kolor itd. ${ }^{10}$.

Zgodnie z przyjętym tu rozumieniem reprezentacji, zgodnym z koncepcją Peirce’a, reprezentacją staje się nośnik informacji, gdy uzyskuje interpretację, która odnosi przekazaną treść (informację ) do przedmiotu. Jakości zmysłowe stają się więc reprezentacjami dopiero wtedy, gdy uzyskują możliwość interpretacji poprzez treść kategorialną i są odniesione do czegoś zewnętrznego. Wtedy zmysłowy bodziec o określonych cechach jest rozpoznawany jako np. obraz psa. Warunkiem pełnienia przez doznania zmysłowe roli reprezentacji poznawczych, a nie

10 Por. F. Dretske, dz. cyt., 26-38. 
informacji sterującej, jest wytworzenie poziomu poznania pojęciowego, który dostarcza dla informacji zmysłowej odpowiedniej interpretacji. Konieczny jest jakiś inny, dodatkowy stan interpretujący, stan będący nośnikiem informacji, aby wytworzyła się relacyjna struktura pełniąca funkcję reprezentacji. W wyniku kolejnych przekształceń przedmiot zmysłowy zostaje ujęty poznawczo jako zespół cech i staje się pojęciem tego przedmiotu oraz rodzajem użytecznej wiedzy o przedmiocie. Na tym poziomie informacja uzyskuje organizację, w której zostaje wyróżniony składnik odniesienia: „o czym jest informacja” i składnik opisu: ,jaka jest jej treść”. Nie jest to już jednak pojedynczy stan reprezentacyjny, ale pełna reprezentacja rozumiana jako struktura relacyjna opisana powyżej.

Gdyby nie wytwarzanie pojęć, poznanie zmysłowe nie mogłoby stać się podstawą wiedzy o świecie, a jedynie stanowiłoby instrukcje reaktywnego działania. Wytworzenie struktury pojęciowej pozwala przechowywać i przetwarzać informacje pochodzenia zmysłowego niezależnie od zmysłowego aktualnego pobudzenia i aktualnej pamięci konkretnych doznan, pozwala operować poznawczo samymi cechami oderwanymi od przedmiotów, z zachowaniem ich intencjonalności czyli możliwości referencji, co z kolei pozwala konstruować reprezentacje pojęciowe zespołów cech niedoświadczanych zmysłowo. ${ }^{11}$ Taka organizacja informacji na poziomie pojęciowym ma swoje podłoże w organizacji trwałej informacji zmysłowej, która zawiera różne doświadczane układy zespołów jakości zmysłowych, zogniskowane w jednym $^{12}$ obiekcie fizycznym. Wytworzona struktura pojęciowa jest trwałą strukturą reprezentacji, służącą następnie do pojęciowej interpretacji zmysłowej informacji chwilowej. Zmysłowe jakości i ich zespoły stają się reprezentacjami, jeśli uzyskują interpretację pojęciową.

11 Dretske wykazuje, że początkiem poznania jest doświadczenie samych jakości. Mamy dostęp do pierwotnego przed pojęciowego ujęcia jakości, przedmiotów doznawanych tylko jako jakieś a nie coś. Jest to poznanie jakie występuje także u zwierząt. Por. F. Dretske, Seeing and Knowing, Routledge, London 1969, 18-35.

12 Proces ten opisał podobnie Quine jako proces reifikacji, por. W.V.O. Quine, $\mathrm{Na}$ tropach prawdy, tłum. z ang. B. Stanosz, Wyd. Spacja, Warszawa 1997, 45-63. 
Istotną własnością ludzkiego aparatu poznawczego jest jego zdolność do wytworzenia społecznego języka, jako systemu transformującego ludzkie poznanie pojęciowe w system znaków zewnętrznych, którymi osoby z nim zaznajomione posługują się dla celów wymiany informacji pomiędzy sobą. Na tym etapie następuje kolejna transformacja informacji zorganizowanej na poziomie pojęciowym w strukturę zewnętrznych reprezentantów. Zgodnie z ideą Peirce'a taka transformacja sprawia, że teraz pojęcia stają się nośnikami informacji, czyli reprezentacjami w dalszym procesie rozwoju znaku a nie jedynie interpretantami poznania zmysłowego. Systemowemu zintegrowaniu podlega, na tym poziomie, informacja zmysłowo-pojęciowa o przedmiocie i informacja o strukturze zewnętrznej reprezentacji językowej. Integracja ta dokonuje się we wrodzonych układach przetwarzania informacji, umożliwiających taki proces. Ich budowa i szczegółowe procesy w nich zachodzące, interesujące same w sobie i badane na poziomie nauki, nie są istotne dla prowadzonych rozważań. Na tym poziomie analizy, ważne jest jedynie odtworzenie w całym procesie przekształcania informacji, etapów wytwarzania coraz bardziej złożonych i abstrakcyjnych typów reprezentacji, obserwowanych na poziomie poznającego podmiotu, takich jak reprezentacje zmysłowe, pojęcia i język. Na kolejnym poziomie, poziomie języka, reprezentacjami stają się zewnętrzne formy wyrażeń, które jako znaki zyskują odniesienia do pojęciowej i zmysłowej reprezentacji świata.

Konstytuowanie się języka przebiega na dwu poziomach: konstytuowania się społecznego systemu znaków oraz integracji tego społecznego systemu z indywidualnym systemem reprezentacji świata każdego użytkownika języka.

Wytworzenie reprezentacji językowej zmienia w ogromnym stopniu naturę i informacyjną organizację systemu reprezentacji poznawczych jednostki, stając się zasadą integracji wszystkich jego poziomów. Problem ten będzie przedmiotem dalszych rozważań. 


\section{ROLA I MIEJSCE JĘZYKA W SYSTEMIE REPREZENTACJI POZNAWCZYCH}

Konrad Lorenz w swej znanej pracy pt. Odwrotna strona zwierciadła podejmuje próbę uzasadnienia stanowiska, że język jako zewnętrzny system znaków rozszerza i zmienia funkcjonalnie strukturę reprezentacji poznawczych. Dyskusja na temat poznawczej funkcji języka formułuje dwie odpowiedzi w powyższej kwestii: język znacznie poszerza możliwości poznawcze człowieka, będąc swoistym narzędziem poznania i sposobem organizacji informacji oraz pogląd przeciwny, że język jest jedynie narzędziem komunikacji i wyrazicielem już zorganizowanego pojęciowo przedjęzykowego poznania. Prowadzone w tej pracy rozważania pokazują, że pojawienie się języka, zmienia i wzbogaca system reprezentacji świata o dodatkowy poziom przetwarzania i organizacji informacji, co pozwala na pełny rozwój i utrwalenie pojęć jako reprezentacji poznawczych. Zmienia on funkcję pojęć, nie są one już tylko interpretacją poznania zmysłowego, ale znajdują swoją interpretację w bardziej rozwiniętej, kolejnej strukturze organizacji informacji. Wyrażenia języka integrują informację zawartą $\mathrm{w}$ pojęciach $\mathrm{z}$ systemem fizycznych, zewnętrznych nośników informacji. Pojęcie związane ze słowem języka znajduje w nim trwałe zakotwiczenie. Jego treść może się rozwijać w strukturze znaków służących komunikacji z innymi.

Aby zewnętrzne nośniki informacji stały się reprezentacjami, powinny one znajdować interpretację w kolejnych procesach informacyjnych. Te procesy to odbiór i rozumienie komunikatu językowego. Jest to możliwe tylko dla społecznego systemu języka posiadającego jako swoje elementy odpowiednie jednostkowe systemy reprezentacji językowych. Sensem, interpretacją (a przynajmniej jej częścią) dla odebranego znaku językowego staje się w procesie jego odbioru treść reprezentacji mentalnej, łączonej z danym dźwiękiem w systemie reprezentacji językowej odbiorcy. Wyrażenie językowe jako określony znak ma przypisaną mu $\mathrm{w}$ danym języku interpretację w postaci informacji, jaką dana osoba w swoim systemie reprezentacji łączy z danym wyrażeniem. Pojawia się naturalne i bardzo istotne sprzężenie zwrotne pozwalające komunikować i interpretować treści poznawcze. To sprzężenie zwrotne prowadzi do utrwalenia i rozwoju systemu pojęciowego, który za sprawą języka 
staje się systemem uzewnętrznionym, społecznym. Słowo/dźwięk jako element świata zjawisk fizycznych może być powtarzalne, wytwarzane dowolnie wiele razy, może stać się stałym odniesieniem, z którym wiąże się określone informacje ${ }^{13}$. Tak więc $\mathrm{w}$ sensie poznawczym reprezentacje umysłowe, będące znaczeniami dla słów, są konstytuowane (jako znaczenia) w obecności języka.

Pojawienie się języka zwiększa, według niektórych stanowisk, możliwości myślenia pojęciowego. Pojęciami, w sposób świadomy i wyraźny dla świadomości, operuje się na poziomie językowym. Tylko w niewielkim stopniu język odzwierciedla gotowe pojęcia, tylko niewielka ilość pojęć i tylko niejasna i ograniczona myśl są możliwe w strukturze poznawczej nie wyposażonej w język ${ }^{14}$. Język, jak ujmuje Paul M. Churchland, jest: „czymś w rodzaju pamięci pozasomatycznej, służy przechowywaniu informacji poza indywidualnymi mózgami nieznikających wraz ze śmiercią. Odkąd pojawił się język, proces poznania otaczającego świata nie ogranicza się już do tego, co może zostać przyswojone w ciągu jednego życia". ${ }^{15}$

Rola języka jest jednak bogatsza. Wprowadza dodatkowy repertuar fizycznych nośników informacji, które wchodzą w opisane wyżej relacje z poznaniem na poziomie zmysłowym i pojęciowym. Pozwala to pojęcia abstrakcyjne, nieposiadające oparcia w odniesieniu do zmysłowych doświadczeń, związać ze zmysłowo postrzeganą formą językową, a przez to uzewnętrznić je i utrwalić, uniezależnić od pojedynczych przeżyć psychicznych.

Sprzężenie zwrotne, jakie powstaje w poznaniu za pomocą języka, pozwala zrozumieć proces stopniowego budowania struktury, której utworzone elementy służą następnie do tworzenia dalszych relacji strukturalnych i kolejnych elementów układu.

Opis poznawczej roli języka powinien ujmować jego funkcję narzędzia służącego myśleniu, funkcję narzędzia stabilizującego i wzbogacającego strukturę pojęciową przez możliwość wiązania „pakietów”

13 Por. W.V.O. Quine, Na tropach prawdy, dz. cyt. 45-63.

14 Por. M. Krąpiec, Język i świat realny, wyd. KUL, Lublin 1985, 88.

15 P. Churchland, Mechanizm rozumu, siedlisko duszy. Filozoficzna podróż w głąb mózgu, tłum z ang. Z. Karaś, Aletheia, Warszawa 2002, 296. 
informacji w stałe i rozróżnialne fizycznie formy, funkcję struktury gromadzącej trwałą wiedzę, funkcję interpretatora informacji chwilowej, która dzięki językowi może być interpretowana pojęciowo i konfrontowana z już posiadanym doświadczeniem zawartym w pamięci. Należy także uwzględnić fakt, że język jest tworzony społecznie, a proces jego akwizycji polega na uzyskaniu przez każdą jednostkę ogromnej ilości informacji zawartej w przyswojonej strukturze znaków.

W tym kontekście znaczenie językowe jawi się jako pewna informacyjna zawartość, przypisana przez interpretację do stanu będącego nośnikiem informacji czy też reprezentacją posiadającą dodatkową charakterystykę funkcjonalną. Zawartość ta przypisana do pojedynczego egzemplarza znaku jest dynamiczna i zależy od procesu konkretnej interpretacji, posiada jednak stałe składniki, jak np. strukturalna informacja nadana przez system reprezentacji. To jednak, w jakiej funkcji reprezentacji pojawia się znak, czy w funkcji interpretacji informacji chwilowej, czy jako element uniwersalnego czy też jednostkowego systemu, zmienia charakter jego znaczenia.

\section{ZNACZENIA JĘZYKOWE JAKO ZESPÓŁ FUNKCJI INFORMACYJNYCH WYRAŻENIA ${ }^{16}$}

Główną myślą wynikającą z rozumienia znaczenia wyrażenia jako konkretnego rezultatu jego interpretacji w całym systemie reprezentacji poznawczych jest postulat, że należy ujmować znaczenie jako zespół kilku funkcji informacyjnych determinujących informację powiązaną z wyrażeniem. Wyrażenie to może wystąpić w różnym odniesieniu, w różnej roli - jako element systemu językowego, element kompetencji językowej użytkownika i element aktu użycia języka. Poszczególne elementy tego zespołu funkcji mogą, w konkretnych wypadkach, odgrywać większą lub mniejszą rolę, co powoduje, że samo znaczenie zmienia swoje własności, raz ujawniając aspekt systemowy, innym razem natomiast kontekstualny, raz ukazując aspekt zależności od użytkownika

$16 \mathrm{Na}$ ten temat pisałam już w artykule: Znaczenie językowe a wiedza o świecie, Studia Philosophiae Christianae 44(2008)2, 5-25. 
języka (indywidualne), innym razem aspekt uniwersalny, podzielany przez całą społeczność językową ${ }^{17}$.

Traktując język jako system znaków, służący w ramach szerszego układu poznawczego do organizowania, przetwarzania, gromadzenia i przenoszenia informacji ${ }^{18}$, można pokazać, że znaczenie przypisane do danego wyrażenia w konkretnym akcie mowy jest wypadkową wielu procesów informacyjnych i funkcji, jakie pełnią reprezentacje poznawcze. Należy bowiem odróżnić znaczenie uniwersalne, jakie wyrażenie posiada jako element systemu językowego, znaczenie użytkownika języka, jakie jest wynikiem akwizycji konkretnego języka przez jednostkę wyposażoną w konkretny zespół doświadczeń, oraz znaczenie konkretnej wypowiedzi uwikłanej w określony kontekst. Różnica stanie się wyraźna, gdy odwołamy się do procesów informacyjnych determinujących poszczególne etapy konstytuowania systemu językowego.

Język jest przede wszystkim system znaków utworzonym społecznie, czyli trwałą strukturą reprezentacji, powiązaną, w opisany w poprzednich częściach sposób, z poznaniem pojęciowym i zmysłowym. W utworzenie tej struktury została zainwestowana znaczna ilość informacji różnego typu. Ta informacja, zwana strukturalną, została zainwestowana tak w budowę samych elementów języka (jako opisanych wyżej relacji znakowych), jak i w utworzenie poziomych i pionowych związków pomiędzy nimi oraz w reguły tworzenia z nich większych kompleksów.

Na poziomie języka społecznego, w procesach wymiany informacji, następuje integracja indywidualnych systemów reprezentacji poznawczych (pojęciowych i zmysłowych) poszczególnych członków wspólnoty językowej ze społecznie wytwarzanym systemem reprezentacji językowej. Integracja struktury pojęciowej jednostki ze społeczną strukturą języka dokonuje się procesie akwizycji języka. Po przyswojeniu przez jednostkę język nie tylko służy do powiązania jej reprezentacji mentalnych z system znaków zewnętrznych, do wyrażania i komunikowania

${ }_{17}$ H. Putnam wskazuje, że znaczenie wyrażenia ma kilka składników; por. Tenże, dz. cyt., 181.

18 Jako taki system ujmuje poznanie F. Dretske, np. w Knowledge and the flow of information, CSLI Publications, Cambridge 1981. 
poznania, ale aktywnie wpływa na organizację $\mathrm{i}$ interpretację informacji zdobywanej w jednostkowym, chwilowym doświadczeniu.

W całościowym procesie organizowania językowego poznania można wyróżnić kilka istotnych dla wyjaśnienia funkcji znaczeniowych, złożonych i powiązanych wzajemnie składowych procesów przetwarzania informacji. Należą do nich: konstytuowanie się kolejnych poziomów reprezentacji poznawczych wraz z poziomem zewnętrznej reprezentacji językowej jako interpretacji poznania zmysłowego i pojęciowego danej jednostki, integrowanie wewnętrznej struktury reprezentacji jednostki z systemem języka społecznego w procesie akwizycji języka, zdobywanie i interpretacja informacji bieżącej (chwilowej) w kontekście języka i zgromadzonej wiedzy osobniczej, tworzenia społecznego systemu wiedzy o świecie sformułowanej językowo, komunikacja międzyosobowa. Nie są to procesy niezależne i odrębne, wprost przeciwnie, są ściśle powiązane i wzajemnie się warunkujące. Każdy z nich może zachodzić tylko w połączeniu z pozostałymi, jednak dla celów wyjaśnienia funkcji i własności języka warto je wyodrębnić

Z każdym z wymienionych procesów przetwarzania i organizacji informacji związana jest inna funkcja informacyjno-znaczeniowa. Kolejno są to: znaczenie rozumiane w sensie ogólnym, systemowym, które jest przypisywane wyrażeniom jako elementom systemu językowego, znaczenie indywidualne, jakie słowom czy wyrażeniom nadaje każdy odrębny użytkownik, znaczenie kontekstowe związane z pojedynczą sytuacją poznawczą czy komunikacyjną oraz znaczenie w sensie odzwierciedlania wiedzy o przedmiocie odniesienia wyrażenia. Wszystkie te procesy, a zatem i funkcje informacyjne znaczenia, są od siebie wzajemnie zależne a odpowiedzialne za nie struktury tworzą jeden zintegrowany system.

Jak było wyjaśnione, każde przekształcenie informacji w systemie wymaga odpowiedniej dla tego procesu struktury, dokonującej transformacji informacji na wejściu w informacje na wyjściu. Ta struktura, aby spełniać swoją funkcję, czyli odbierać i przetwarzać wysoko zorganizowane przekazy, musi posiadać wystarczającą ilość wcześniej zainwestowanej informacji. Gromadzenie informacji dokonuje się hierarchicznie i rekurencyjnie. Hierarchicznie, gdyż na każdym kolejnym szczeblu systemu (jakości zmysłowe, pojęcia, wyrażenia) operujemy 
bardziej złożonymi „pakietami” (kompleksami) informacji. Rekurencyjność procesu oznacza, że układ musi posiadać określoną informację strukturalną, aby mógł odebrać przekazaną mu kolejną informację, która włączona w strukturę systemu, umożliwi przyjęcie kolejnej informacji itd.

Ukonstytuowanie się i rozwój struktury społecznej języka jest istotnym, końcowym etapem organizacji opisanego wyżej systemu reprezentacji poznawczych. Język (np. dowolny język naturalny) jest przede wszystkim społecznie wytworzoną strukturą reprezentacji poznania. Pojawia się on w efekcie uzewnętrznienia i integracji indywidualnego poznania świata różnych jednostek w służący komunikacji system symboli. Język tak rozumiany jest społeczną reprezentacją poznania świata w znakach zewnętrznych. Jego struktura musi być odpowiednio bogata, aby mogła przyjmować i przetwarzać złożone informacje, jakich wymaga taka forma reprezentowania.

Z każdym elementem reprezentacji językowej związana jest odpowiednia informacja strukturalna, determinująca jego budowę wewnętrzną, jego systemowe relacje, reguły łączenia z innymi elementami itd. Część informacji strukturalnej związanej w danym znaku i stanowiącą jego treść językową można nazwać jego znaczeniem systemowym, ogólnym. Niesie ono uogólnione, schematyczne i względnie stałe informacje strukturalne, systemowo związane z danym wyrażeniem języka. Każdy, kto przyswaja sobie dany język, przyswaja też daną treść wyrażenia. Ze względu na systemowe relacje, znaczenie każdego elementu w strukturze reprezentacji może być wyznaczone przez inne elementy systemu, czyli dane w postaci opisu językowego (wewnątrzsystemowego).

Znaczenie, jakie pojawia się na tym poziomie, jest ponadindywidualne, uniwersalne, jest skonwencjonalizowaną wiedzą, związaną strukturalnie dla potrzeb reprezentacji. Informacja związana z tym znaczeniem jest zgromadzona na kilku poziomach struktury językowej, odzwierciedlających relacje znaków językowych do świata (funkcja odniesienia), relację do systemu języka (funkcja sensu czyli ujawnianiu treści językowej poprzez odsłanianie relacji do innych znaków) i relacji do użytkowników języka, która przejawia się w związku znaczenia w sensie uniwersalnym $\mathrm{z}$ indywidualnym doświadczeniem 
użytkowników, czyli w znaczeniach indywidualnych. To systemowe znaczenie, ukonstytuowane przez system reprezentacji, jest podstawą dla wszelkich użyć i kontekstualnych interpretacji znaczenia jako informacji chwilowej.

Język społeczny wyrasta z doświadczenia świata indywidualnych użytkowników języka. Każdy z nich posiada swój własny system poznawczy, swoją indywidualną strukturę reprezentacji poznania, którą system języka społecznego integruje na poziomie indywidualnym i społecznym. Dokonuje się to w procesie akwizycji języka.

Akwizycja języka wymaga (obok języka nabywanego) odpowiedniej struktury gromadzenia i przetwarzania informacji na poziomie indywidualnego użytkownika. Takiej, w której dokonuje się synchronizacja i integracja zmysłowej wiedzy jednostkowej, ujętej w przedjęzykowe pojęcia ze strukturą języka nabywanego. W tym procesie słowa języka nabierają indywidualnej treści dla danego użytkownika, pochodzącej od jego doświadczenia świata, ale jednocześnie zsynchronizowanej $\mathrm{z}$ treścią wyznaczoną systemowo. Wymaga to istnienia określonych wrodzonych struktur biologicznych umożliwiających takie przetwarzanie informacji. Noam Chomsky, Jerry Fodor, Anna Wierzbicka i inni postulują też istnienie wrodzonych elementów semantycznych lub gramatycznych języka, umożliwiających jego zaawansowany rozwój.

Przyswajany język wprowadza odpowiednią organizację w strukturze pojęciowej przyswajającego. Wnosi wiele dodatkowej informacji, zarówno przedmiotowej, jak i strukturalnej. Wzbogaca i zmienia pierwotną organizację przedjęzykowej wiedzy i staje się narzędziem zdobywania nowej informacji.

Na poziomie indywidualnego użytkownika, ze słowem wyposażonym w abstrakcyjne znaczenie ogólne (systemowe) wiązana jest dodatkowa informacja, wniesiona przez indywidualne doświadczenie zmysłowe świata. Znaczenie indywidualne zawiera informacje systemowe, wprowadzone w procesie akwizycji języka i informacje pochodzące $\mathrm{z}$ doświadczenia jednostki, różne dla każdego użytkownika. Jednostka wyposażona $\mathrm{w}$ język posiada indywidualny system przetwarzania informacji zdobywanej w bieżącym doświadczeniu w formę społecznie funkcjonującego języka. 
Zdobywanie informacji aktualnej i jej interpretacja zachodzi w kontekście posiadanego języka. Po nabyciu języka, percepcja i jej pojęciowa interpretacja, jak też wszelka komunikacja dokonują się z jego udziałem. Proces interpretacji bieżącej informacji uaktywnia struktury języka, ale też i cały zakres wiedzy o świecie dostępny użytkownikowi. Obserwuje się zjawisko dodawania do interpretowanego sygnału standardowej informacji na podstawie wcześniejszej wiedzy ogólnej. Np. chemik, interpretując występowanie wody w pewnej sytuacji laboratoryjnej, będzie uzupełniał standardowe językowe znaczenie słowa woda informacją naukową o jej strukturze chemicznej, podczas gdy np. ratownik w czasie powodzi jej własnościami niszczycielskimi. Na tym poziomie przetwarzania informacji integrowana jest zewnętrzna informacja dana $\mathrm{w}$ pojedynczym przekazie $\mathrm{z}$ wiedzą posiadaną przez jednostkę. Informacja uzyskiwana w danej sytuacji modyfikuje informację standardowo łączoną z danym sygnałem lub przekazem. Można tu mówić o czymś, co nazywane jest znaczeniem kontekstowym. Znaczenie kontekstowe to doraźna informacja przypisana użyciu wyrażenia w danej sytuacji poznawczej czy komunikacyjnej. Na tym poziomie struktury społecznego i indywidualnego poznania znaczenia te są narzędziem w podstawowym procesie zdobywania bieżącej informacji o otoczeniu niezbędnej do przetrwania i celowego działania.

Wytwarzanie wiedzy o świecie jest wzbogacone przez istnienie struktury językowej. Zdobywanie informacji aktualnej i jej przetwarzanie w formę językową umożliwia tworzenie społecznej wiedzy o świecie. W procesach zdobywania informacji aktualnej zachodzi wzajemne dwukierunkowe oddziaływanie języka i świata. Ze strony języka zaznacza się wpływ na konceptualizację i rozumienie zjawisk. Otoczenie dostarcza informacji, która staje się wiedzą o świecie i zmienia (powoli) strukturę (np. znaczeniową) języka. W procesie interpretacji sygnałów możemy natrafić na informacje nie poddające się interpretacji w świetle istniejącej wiedzy. Sytuacja taka będzie prowadzić bądź do wzrostu wiedzy, bądź do zmiany znaczeniowej struktury reprezentacji.

Struktura reprezentacji językowej jest celowo podporządkowana wytwarzaniu wiedzy o świecie, istnieje zatem silne sprzężenie zwrotne pomiędzy wiedzą encyklopedyczną a znaczeniem słów. Pod wpływem 
zdobywanej wiedzy przebudowuje się struktura reprezentacji w system bardziej odpowiadający spójnemu opisowi świata.

Jednak znaczenie językowe i wiedza encyklopedyczna nie są tym samym. Znaczenie jest elementem strukturalnym języka, który jest narzędziem zdobywania wiedzy. Wiedza zgromadzona w strukturze języka jest znaczeniem, a wiedza encyklopedyczna jest dodatkową informacją zgromadzoną za pomocą języka.

Komunikacja leży u podstaw integracji przedjęzykowych, reprezentacji świata w początkowo ubogi język społeczny a następnie umożliwia jego ciągły rozwój. Gwarantuje synchronizację systemu i jest narzędziem wymiany informacji za pomocą języka pomiędzy użytkownikami języka.

W procesie komunikacji językowej wyrażenie językowe jest nośnikiem informacji systemowej, ale interpretacja tej informacji przebiega w kontekście sytuacji komunikacji i wiedzy interpretującego. Dlatego rozumienie wypowiedzi ma obok systemowego, obiektywnego uniwersalnego składnika znaczenia także element kontekstu i wiedzy indywidualnej użytkownika. Znaczenie wypowiedzi jest jednak genetycznie związane z systemowym znaczeniem wyrażeń i poznawczym uwarunkowaniem języka.

\section{PODSUMOWANIE}

Ta bardzo krótka i uproszczona analiza procesów, w jakich konstytuuje się system języka, aby być narzędziem komunikacji, pokazuje, że mówiąc o znaczeniu, mamy na myśli wiele różnych funkcji wyposażania wyrażenia w związaną z nim informację. Jak pokazano, informacja ta ma wiele różnych źródeł i zostaje przypisana do wyrażenia na różnych etapach konstytuowania się społecznego systemu języka. Podstawowa jest informacja zgromadzona w systemie językowym, która nadaje znaczenie uniwersalne, systemowo przypisane do wyrażenia. Jest ono jednak ogólne, schematyczne i odniesione do indywidualnego doświadczenia świata przez znaczenie indywidualne, jakie wyrażeniu nadaje konkretny użytkownik języka na podstawie tego, co stanowi jego kompetencję językową. Możemy zatem mówić zarówno o pewnym uniwersalnym, wspólnym dla wszystkich znaczeniu, jak i o znaczeniu 
indywidualnym, które ma pewien rys właściwy tylko danemu użytkownikowi. Jedno jest bardziej abstrakcyjne, a drugie wypełnione treścią doświadczenia. Należy także wyróżnić znaczenie związane z konkretnym użyciem, jako odniesione do procesu zdobywania informacji chwilowej, najbardziej nasycone elementami kontekstu.

To, co uznajemy za znaczenie wypowiedzi (w sensie informacji przekazanej przez wyrażenia) w konkretnej sytuacji, jest wypadkową różnych funkcji informacyjnych jakie pełni język, od znaczenia konwencjonalnego po kontekstowe. Dlatego w kontekście poruszanych zagadnień bardziej właściwe jest mówić o różnych funkcjach informacyjnych znaczenia. W tym sensie nie ma opozycji pomiędzy wymienionymi na wstępie sposobami rozumienia znaczenia. Każdy z nich ujmuje znaczenie w inne aspekty funkcji informacyjnej.

Jeśli mówimy o języku, odwołując się do jego funkcji reprezentacji świata, odwołujemy się do znaczenia systemowego, wyznaczającego warunki prawdziwości wyrażeń dla wszystkich użytkowników języka. Jeśli natomiast uchwytujemy w języku jednostkowe zdarzenie lub wypowiedź, dodajemy w interpretacji do znaczenia systemowego cały szereg informacji kontekstowych, które pozwalają nadać wypowiedzi jej unikatowe, jednorazowe znaczenie.

Przyjęcie perspektywy uwzględniającej poznawczą genezę języka, pozwala wskazać związki pomiędzy różnorodnymi sposobami, w jakich mówimy o znaczeniu językowym.

\section{BIBLIOGRAFIA}

Buczkowska J., Systemowe rozumienie języka, Wydawnictwo UKSW, Warszawa 2002.

Buczkowska J., Znaczenie językowe a wiedza o świecie, Studia Philosophiae Christianae 44(2008)2, 5-25.

Buczkowska J., O relacyjnej i informacyjnej naturze reprezentacji, Wydawnictwo UKSW, Warszawa 2012, 103-119.

Churchland P., Mechanizm rozumu siedlisko duszy. Filozoficzna podróż w głąb mózgu, tłum Z. Karaś, Aletheia, Warszawa 2002.

Cummnis R., Meaning and Mental Representation, MIT Press, London 1989. 
Dretske F., Seeing and Knowing, Routledge, London 1969.

Dretske F., Knowledge and the flow of information, CSLI Publications, Cambridge 1981.

Dretske F., Naturalizowanie umystu, thum z ang. B. Świątczak, Wydawnictwo IFiS PAN, Warszawa 2004.

Krąpiec M., Język i świat realny, wyd. KUL, Lublin, 1985.

Nagel T., Co to wszystko znaczy. Bardzo krótkie wprowadzenie do filozofii, tłum. z ang. M. Szczubiałka, Fundacja Aletheia, Warszawa 1998.

Putnam H., Znaczenie wyrazu znaczenie, w: tegoż, Wiele twarzy realizmu $i$ inne eseje, tłum z ang. A. Grobler, PWN, Warszawa 1998, 93-184.

Quine W.V.O., Na tropach prawdy, z ang. tłum. B. Stanosz, Spacja, Warszawa 1997.

Quine W. V.O., Dwa dogmaty empiryzmu, w: tegoż, Z punktu widzenia logiki, tłum. z ang. B. Stanosz, Fundacja Aletheia, Warszawa 2000, 49-75.

Russell B., Miękkie i twarde dane, w: Filozofia percepcji, Fragmenty filozofii analitycznej, tłum. R. Godlewski, red. B. Chwedeńczuk, wyd. Spacja, Warszawa 1995, 11-22.

Taylor J. R., Kategoryzacja w języku. Prototypy w teorii językoznawczej, thum. z ang. A. Skucińska, TAiWPN Universitas, Kraków 2001.

\title{
THE COGNITIVE ORIGINS OF LANGUAGE AND THE INFORMATIONAL STRUCTURE OF LINGUISTIC MEANING
}

\begin{abstract}
In this paper I would like to propose an explanation of a variety of aspects in which linguistic meaning manifests itself in cognition and linguistic communication from the perspective of the cognitive origins of language. The analysis shows that language is understood as a system of cognitive representations, within which the specific processes of information processing occur. These processes taking place in the human cognitive system are the basis of the relationships between language and human cognition and action. They are also a source of the linguistic meaning and its various informational functions.

The analysis shows that no single informational function of language provides linguistic meaning. What is consider to be the linguistic meaning (in the sense of the information submitted by the expression in a specific situation) is not a single function of language, the same in all these processes, but it is rather a complex of different informational functions that language fulfills (for
\end{abstract}


example conventional meaning fulfill different function then contextual one). Such an explanation allows us to identify the mutual relationships of different functions and aspects of the linguistic meaning and recognize them as complementary rather than oppositional.

Keywords: language, meaning, cognitive representations, information, informational structure of representation 